\title{
Association between Cancer and Environmental Exposure to Glyphosate
}

\author{
Medardo Avila-Vazquez ${ }^{*}$, Eduardo Maturano ${ }^{2}$, Agustina Etchegoyen ${ }^{3}$, \\ Flavia Silvina Difilippo', Bryan Maclean'1
}

${ }^{1}$ Faculty of Medical Sciences, National University of Cordoba, Cordoba City, Argentina

${ }^{2}$ Epidemiology Committee of Virology Institute Jose Maria Vanella, Faculty of Medical Sciences, National University of Cordoba, Cordoba City, Argentina

${ }^{3}$ Center for Environmental Research, Faculty of Exact Sciences, National University of La Plata, La Plata City, Argentina Email: ^medardoavilavazquez@yahoo.com.ar, eduardo_maturano@yahoo.com.ar, agustinaetchegoyen@gmail.com, flaviadifilippo@gmail.com, bryandelrio@yahoo.com.ar

How to cite this paper: Avila-Vazquez, M., Maturano, E., Etchegoyen, A., Difilippo, F.S. and Maclean, B. (2017) Association between Cancer and Environmental Exposure to Glyphosate. International Journal of Clinical Medicine, 8, 73-85. https://doi.org/10.4236/ijcm.2017.82007

Received: December 30, 2016

Accepted: February 18, 2017

Published: February 21, 2017

Copyright (c) 2017 by authors and Scientific Research Publishing Inc. This work is licensed under the Creative Commons Attribution International License (CC BY 4.0).

http://creativecommons.org/licenses/by/4.0/

cC) (i) Open Access

\begin{abstract}
Background: Argentina, Brazil, Paraguay and Uruguay farm transgenic seeds glyphosate resistant. Argentina annually utilizes 240,000 tonnes of glyphosate in agriculture. A change in the profile of morbidity and mortality is perceived in agricultural areas; cancer seems to prevail. Monte Maíz is a typical argentine agricultural town with 8000 inhabitants; the Mayor and residents of Monte Maiz requested an environmental health study due to perceived increase in cancer frequencies. Methods: An exploratory ecological study was developed to assess the urban environmental contamination and the frequencies and distribution of cancer through an environmental analysis of pollution sources including measurements of pesticides in water, soil and grain dust, and a cross-sectional study of cancer patients that explore associations with different variables. Results: Glyphosate was detected in soil and grain dust and was found to be at an even higher concentration in the village soil than in the rural area. 650 tonnes are used annually in the region and manipulated inner town. We do not find other relevant sources of pollution. Cancer incidence, prevalence, and mortality are between two and three times higher than the reference values (Globocan 2012, WHO) for the entire nation $(706 / 100,000$ persons vs. $217 / 100,000 ; 2123 / 100,000$ persons vs. $883.82 / 100,000$ and $383 / 100,000$ persons vs. $115.13 / 100,000$, respectively). Conclusion: This study detects high glyphosate pollution in association with increased frequencies of cancer in a typical argentine agricultural village, and by design, cannot make claims of causality. Other study designs are required, but if we corroborate the concrescence of high exposure to glyphosate and cancer.
\end{abstract}




\section{Keywords}

Glyphosate, Pesticides, Cancer, Environmental Health, Environmental Exposure

\section{Background}

In 1996, Argentina began to grow genetically modified (GM) seeds, and used currently 25 million hectares where 12 million people live; these crops have generated a substantial increase in the pesticide consumption. In 2013, Argentina sprayed 240,000 tons of Glyphosate [1] [2]. A change in the profile of morbidity and mortality is perceived for physicians of agricultural areas; now cancer seems to prevail [3]. Epidemiological and experimental researchers suggest a positive association between glyphosate and cancer, as recently reported by the International Agency for Research on Cancer (IARC)-World Health Organization [4].

The town Monte Maiz (Union District in Province of Cordoba) lies at the heart of Argentina's agricultural area, a region of greater agricultural productivity in the country, where soy, maize, and wheat are grown, and is in the center of the country. In recent years, local governmental authorities along with local residents and doctors were worried about an increase apparent in the number of people suffering from diseases like cancer and thus requested an assessment of health status to the Faculty of Medical Sciences, National University of Cordoba (UNC). The community had conducted a health census in 2007 (unpublished), carried out by teachers and other volunteers, in which high rates of cancer were identified. Also, the Provincial Tumors Registry of the Province of Cordoba (RPT) reported that Union District has a higher cancer mortality rate than that recorded in Cordoba City [5]; nevertheless, there are few epidemiological studies on the environmental health of rural populations in Argentina and very little has been published to date.

The objective of this study of the Monte Maíz environmental contamination recorded mainly, the presence of glyphosate and other pesticides and checked whether the incidence, prevalence, and mortality of cancer were increased. It was our goal to verify concurrence of glyphosate exposure and cancer.

\section{Material and Methods}

An exploratory ecological study on cancer and environmental pollution was performed. Consisting on the one hand of an epidemiological study (a crosssectional study) with a household survey of health orientation of the whole population (population survey), designed to geo-reference each record in the village with use of nine ratios census $(\mathrm{R})$ by National Institute Census that divide the town into nine sectors outweighed demographically as seen in the map of Figure 1. Through the household survey, we checked cancer prevalence (living residents diagnosed in the last 5 years with oncological disease in any location), cancer incidence 2014 (new cases diagnosed last year) and cancer mortality (deaths 


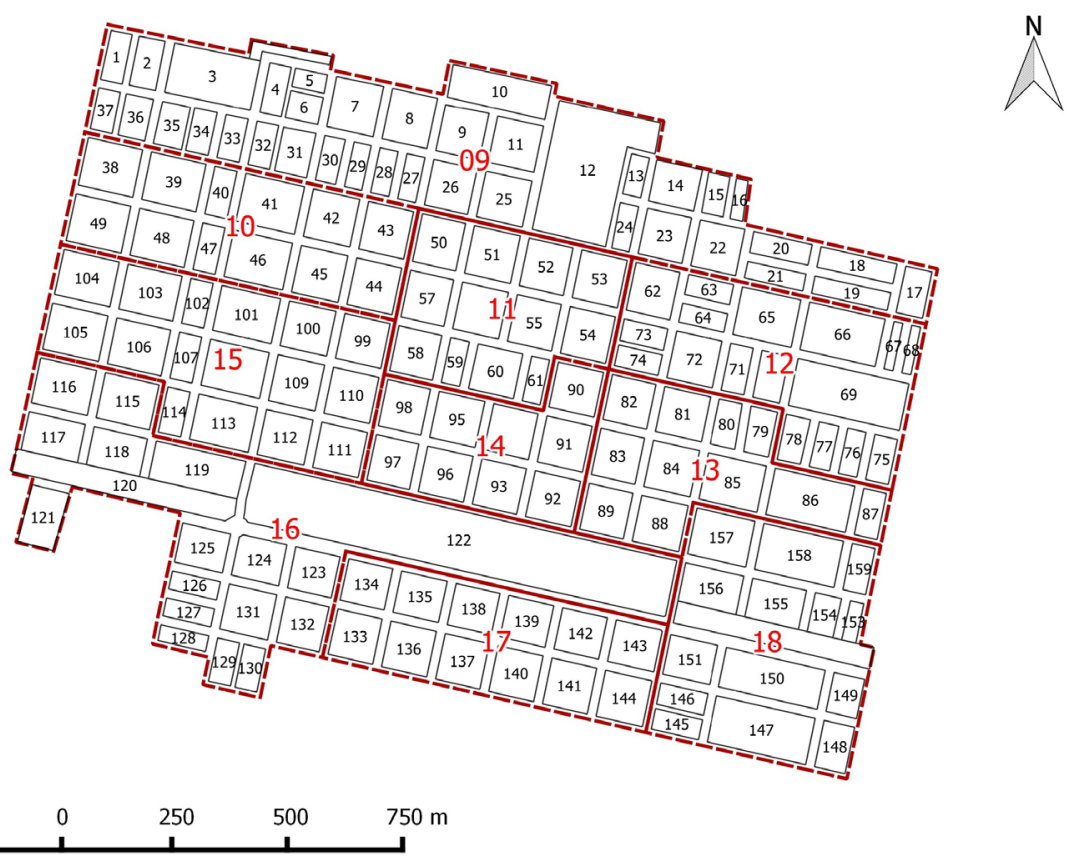

Figure 1. Map of the Census Radius of Monte Maíz by National Institute Census divides the town into nine sectors outweighed demographically, from in number 9 to number 18.

from cancer in the last year and the past 5 years), for criteria of Globocan 2012 [6], these three were dependent variables, while sex, age, occupation, stay in the village, smoke, ratio census residence, educational level and the presence of environmental contaminants were the independent variables.

On the other hand, an environmental analysis recording sources of contamination such as landfills, cell site (cell tower), electric power transformers, industrial sites, stockpiles of grains, storehouses of pesticides, and spraying machines. We interviewed community and government stakeholders, business owners, city officials, teachers, farmers and workers that sprayed pesticides, in order to recognize the performance of industries, local public services, and agribusiness (drinking water, sewer management, household waste, industries pollutions, routines and doses of pesticides use).

Samples of environmental matrices (water, soil, grain husks) were collected and analyzed by the Center for Environmental Research, Faculty of Exact Sciences of National University of La Plata, which selected twelve internal and peripheral sites in the town to examine the presence of glyphosate, its metabolite aminomethylphosphonic acid (AMPA), and currently used pesticides (chlorpyrifos, endosulfan, atrazine, $2.4 \mathrm{D}$, and epoxiconazole). Both pretreatment and analysis of pesticides were performed under international regulations using liquid chromatography-mass spectrometry [7] [8]. A dosage of arsenic (As) was conducted in domestic water network using hydride generation atomic absorption spectrometry.

The study area was Monte Maíz, a town located on Provincial Route $\mathrm{N}^{\circ} 11^{\prime}$, $33^{\circ} 12^{\prime}$ South latitude and $62^{\circ} 36^{\prime}$ West longitude of Greenwich, at a height above 
sea level of 114 metres; the town is 113 years old and has 7788 inhabitants (8045 including residents of surrounding rural areas). Agriculture is the main economic activity with complementary metalworking industry that is located on the Southern edge of the town [9].

\subsection{Statistical Analysis}

Crude rates were obtained through a database and numerical matrix. The incidence rate was age adjusted to the structure of the population of Cordoba city by the indirect method. A bivariate correlation Pearson analysis conducted to assess the association of cancer with independent variables, included the spatial distribution according to ratios census in which the town was divided (R09-R18). We built maps for cancer and pollution sources using Quantum GIS 2.4 software and created contingency tables to perform relational measurements between exposure and disease. For this end, the following software was used: INFOSTAT (UNC), SPSS, and EPIDAT (PAHO). Rates of cancer incidence, cancer prevalence and cancer mortality of Monte Maíz were compared with the same rates for Cordoba city (reference big city in the province), for the whole province and for the entire country, according to RPT [5], the National Health Ministry [10] and Globocan 2012 [6].

\subsection{Study Conduct}

Physicians or medical students carried out the fieldwork during October 2014; all health surveys were conducted by final year medicine students of UNC and medical professors. The study was conducted in accordance with the Declaration of Helsinki and under the framework of Act 9694 Article 2 of the Province of Cordoba in accordance with the law regulating health research and was approved by the Bioethics Committee established by this law for observational studies [11]. All surveys were performed after obtaining informed consent.

\section{Results}

\subsection{Environmental Analysis}

In Monte Maíz the electrical network is powered by medium-voltage power distributed in the urban area, with substations of $33 \mathrm{kV}$ to $380 \mathrm{w}$, no high voltage. Has a sewer system with a domestic collection network reaching every home; solid urban waste is collected by a municipal service that has a Solid Waste plant. Their hinterland has soybeans on 45,000 ha and maize on 20,000 ha which are main summer crops and wheat on 15,000 ha as a winter crop. We identified an open landfill, 800 meters northeast of the town's limit, with no evidence of fire in the last 5 years. There is an absence of forestry across the periphery of the town, which is replaced by soybean and maize crops, starting at the immediate edge of houses. These crops are frequently treated, with pesticide, by ground equipment and crop dusters. At the southwest of Monte Maíz, we found two livestock breeding farms, and, on the west side, a flood zone, with ponds, a park, and a sewage treatment plant between the crop fields. 
There are two farm equipment industries, located at the southern tip of the town; these factories use methane gas as a source of energy. The sources of electromagnetic radiation were two cellphone towers, located in R9 and R12 which are highlighted on the map of pollution factors on Monte Maíz in Figure 2 (there are two other towers located outside of the urban area). The population of Monte Maíz receives drinking water of very good quality, drinkable and arsenic-free. Within the inhabited village, there are silos of cereal from where soy and corn husks are released (grain dust) shown on the map in Figure 2 and were identified twenty-two deposits for spraying machines and pesticide containers used in the region.

Local agronomists and agrochemical applicators report that in Monte Maíz GM soybean and corn crops use 10 kilograms of glyphosate per ha per year. Six hundred and fifty tonnes of glyphosate are aerosolized in the area, creating a general burden of environmental exposure to glyphosate of $79 \mathrm{~kg}$ per person per year, which varies for agricultural or non-agricultural activity and for spatial distribution of glyphosate. This region utilizes $975 \mathrm{t}$ of all pesticides each year.

Chemical contaminants test: Herbicide glyphosate and AMPA was detected in $100 \%$ samples of soil and husk. In grain husks from silos, glyphosate and AMPA prevailed (505 and $607 \mathrm{ppb}$ ), followed by chlorpyrifos (14 ppb) and epoxiconazole (2.3 ppb) as shown in Table 1 . Sampling site $\mathrm{N}^{\circ} 6$ (map in Figure 2), belonging to a children's playground, contained 68 times more glyphosate than site $\mathrm{N}^{\circ} 5$, belonging to a farm field of corn resistant to glyphosate. Similarly, site $\mathrm{N}^{\circ} 8$, where the soil sample was taken from the sidewalk next to pesticides deposits, had the highest concentration of glyphosate (3868 ppb), AMPA (3192 ppb), and other pesticides.

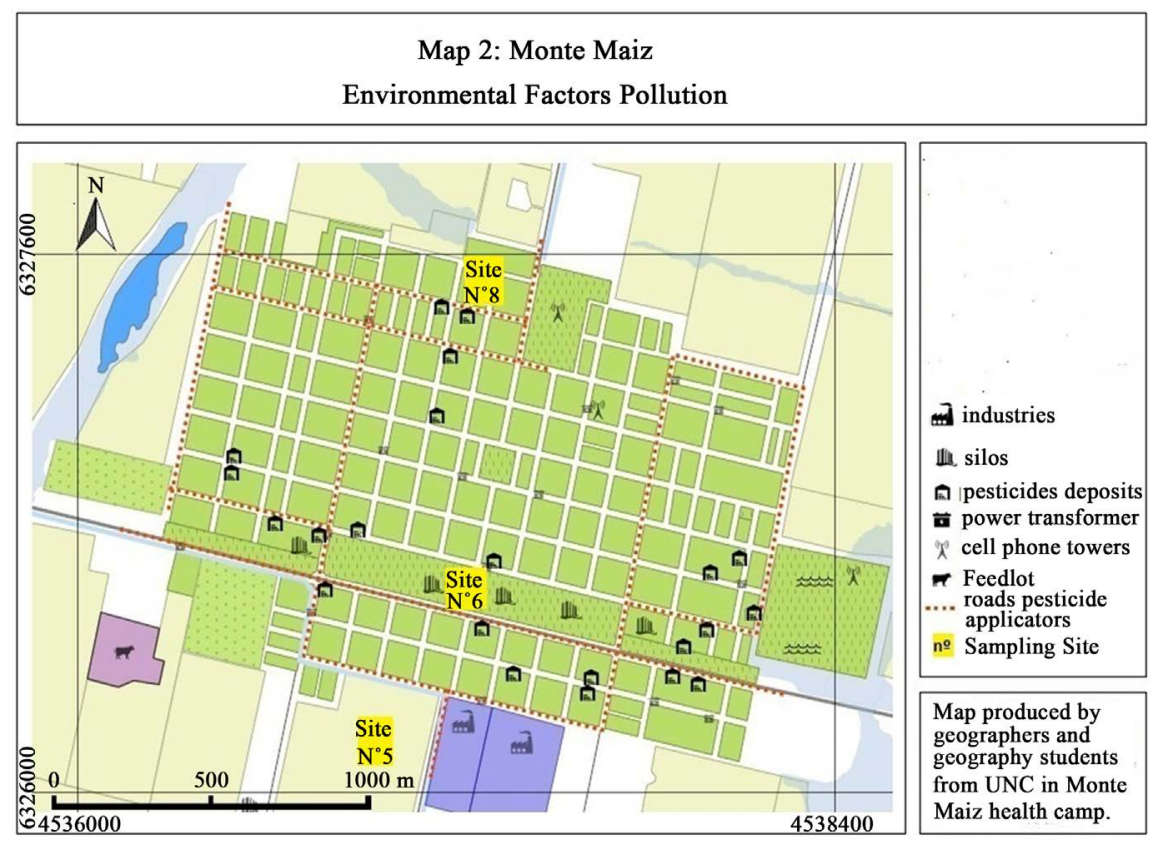

Figure 2. Map of environmental factors of pollution on Monte Maíz and main sampling site. 
Table 1. Measurements pesticides in environmental matrices, main findings. Reference S located sampling site (S5, S6 and S8) in map of Figure 2. DNC: Detectable no quantifiable. Center for Environmental Research, Faculty of Exact Sciences of National University of La Plata.

\begin{tabular}{cccccccccc}
\hline S: Site sampling & Glifosato & AMPA & $2.4 \mathrm{D}$ & Atrazina & Clorpirifos & Endosulfan I & Endosulfan II & Cipermetrina & Epoxiconazol \\
\hline $\begin{array}{c}\text { S1 drinking } \\
\text { water network }\end{array}$ & $<2 \mathrm{ppb}$ & $<2 \mathrm{ppb}$ & $<1 \mathrm{ppb}$ & $<0.5 \mathrm{ppb}$ & $\mathrm{DNC}$ & $\mathrm{DNC}$ & $\mathrm{DNC}$ & $<0.005 \mathrm{ppb}$ & $<0.005 \mathrm{ppb}$ \\
S5 crop field soil & $41 \mathrm{ppb}$ & $116 \mathrm{ppb}$ & $<5 \mathrm{ppb}$ & $6.4 \mathrm{ppb}$ & $242 \mathrm{ppb}$ & $<1.5 \mathrm{ppb}$ & $2.2 \mathrm{ppb}$ & $58 \mathrm{ppb}$ & $3 \mathrm{ppb}$ \\
$\begin{array}{c}\text { S6 children's } \\
\text { playground soil }\end{array}$ & $2792 \mathrm{ppb}$ & $797 \mathrm{ppb}$ & $\mathrm{S} / \mathrm{D}$ & $\mathrm{S} / \mathrm{D}$ & $4.4 \mathrm{ppb}$ & $<1.5 \mathrm{ppb}$ & $<1.5 \mathrm{ppb}$ & $4 \mathrm{ppb}$ & $3.4 \mathrm{ppb}$ \\
$\begin{array}{c}\text { S6 children' } \\
\text { playground grain } \\
\text { husks from silos }\end{array}$ & $505 \mathrm{ppb}$ & $607 \mathrm{ppb}$ & $\mathrm{S} / \mathrm{D}$ & $\mathrm{S} / \mathrm{D}$ & $14 \mathrm{ppb}$ & $\mathrm{DNC}$ & $<1.5 \mathrm{ppb}$ & DNC & $2.3 \mathrm{ppb}$ \\
$\begin{array}{c}\text { S8 pesticides } \\
\text { deposits soil }\end{array}$ & $3868 \mathrm{ppb}$ & $3192 \mathrm{ppb}$ & $128 \mathrm{ppb}$ & $52.5 \mathrm{ppb}$ & $150.4 \mathrm{ppb}$ & $17.5 \mathrm{ppb}$ & $338 \mathrm{ppb}$ & $180 \mathrm{ppb}$ & $6.3 \mathrm{ppb}$ \\
\hline
\end{tabular}

Glyphosate also had the highest concentrations among all the matrices studied (3868 ppb), exceeding by far the other pesticides: endosulfan II (337.7 ppb) and chlorpyrifos (242 ppb) (see Table 1). There were minimal concentrations of pesticides in drinking water, also, the arsenic in drinking water was less than $5 \mathrm{ppb}$.

\subsection{Epidemiological Analysis}

Overall, $92 \%$ households were visited, $4.8 \%$ corresponds to households that refused to answer the survey. Some houses were uninhabited at the time of the visit. The information was collected from 4859 people ( $62 \%$ of the population), its characteristics are available in Table 2.

The crude cancer incidence rate 2014 was $706 / 100,000$ persons (n: 35/4954), and age-adjusted rates (indirect method) was 980/100,000 (CI: 655-1305) for Monte Maíz, in Cordoba city (used as reference population) this rate was 469/ 100,000 confidence interval (CI): 453-484 and. The crude prevalence rate was 2123/100,000 persons (n: 104/4898).

The most common locations of cancer was found in breast 29\% (n: 30/104), colon $10 \%(\mathrm{n} ; 11 / 104)$, prostate $8 \%(\mathrm{n}: 9 / 104)$, thyroid $8 \%(\mathrm{n}: 8 / 104)$, and skin $7 \%$ (n: 7/104). In relation to the age of patients, $22 \%$ of patients with cancer of Monte Maíz have less than 44 years old age.

The 2014 cancer mortality rate was 383/100,000 persons. Between 2010 and 2014, there were 68 confirmed cancer deaths (rate: 274/100,000). According to death certificates in 2013 and 2014, cancer deaths made up 39\% and 34\% of all deaths (Table 3).

Pearson correlation showed a link between cancer prevalence and R15 (people living in census radius $n^{\circ} 15$ ) and cancer incidence with groups who engage in agricultural activities. Odds ratio (OR) for the prevalence of cancer in R15 was 2.15 (CI: $1.35-3.42) p=0.0009$, and incidence of cancer in agricultural families was 3.5 (CI: 1.45 - 8.58) $p=0.002$. Smoking showed no relationship with cancer incidence or prevalence in Monte Maíz. 
Table 2. Monte Maíz population surveyed: characteristics, absolute numbers and percentages

\begin{tabular}{cc}
\hline Characteristics & Magnitude \\
Male & $4959(61.98 \%$ of population total) \\
Female & $2361(47.61 \%)$ \\
Average age of Population & $2597(52.37 \%)$ \\
People 0 - 15 years & 36.03 years \\
People $\geq 16$ years with complete primary education & $1175(23.69 \%)$ \\
People with health insurance & $3313 / 3744(88.49 \%)$ \\
Percentage of people with $\geq 5$ years residence time & $3859(78.01 \%)$ \\
Families of rural workers, farmers and agronomists & $4141 / 4328(95.68 \%)$ \\
Smokers & 270 families (970 people) \\
\hline
\end{tabular}

Table 3. Cancer data summary and its comparison to reference data.

\begin{tabular}{|c|c|c|}
\hline & Monte Maíz & Reference \\
\hline Crude Cancer Incidence Rate 2014 & $706 / 100,000$ & 259.4/100,000 Cordoba City* \\
\hline Crude Cancer Incidence Rate 2014 & $706 / 100,000$ & $217 / 100,000$ Argentina $2012^{* *}$ \\
\hline $\begin{array}{l}\text { Indirect Adjustment } \\
\text { Cancer Incidence Rate }\end{array}$ & $\begin{array}{c}980 / 100,000 \\
(\mathrm{CI}: 655-305)\end{array}$ & 469/100,000 Cordoba City \\
\hline New cases per year (incidence) & 35 cases/year & 13.9 cases/year Cordoba $(\mathrm{RPT})^{*}$ \\
\hline Cancer Prevalence Rate & $2123 / 100,000$ & $884 / 100,000$ Argentina $2012^{\star *}$ \\
\hline Cancer patients $<44$ years (percent) & $22 \%$ & $11 \%^{*}$ \\
\hline Relative Risk of cancer $<44$ years & 1.88 (CI: $1.31-2.70)$ & 1 Province of Cordoba \\
\hline Cancer Mortality Rate/100,000 & 383 year 2014 & 128 Cordoba City Year 2009* \\
\hline Average Cancer Mortality Rate 5 years & $274 / 100000$ & 135 Cordoba City ${ }^{\star}$ \\
\hline Cancer Mortality 2013 (percent) & $38.7 \%(2013)$ & $20 \%$ Córdoba City $(2010)^{\star * \star}$ \\
\hline Cancer Mortality 2014 (percent) & $33.9 \%(2014)$ & $20 \%$ Cordoba City $(2010)^{* * *}$ \\
\hline
\end{tabular}

${ }^{\star}$ Data source: Provincial Tumors Registry of the Province of Cordoba (RPT); ${ }^{*}$ Data source: Globocan 2012, International Agency for Research on Cancer (IARC)-World Health Organization; ${ }^{\star *}$ Data source: Estadísticas vitales. Ministerio de Salud. Provincia de Córdoba

\section{Discussion}

Seeds that are genetically manipulated to contain a transgene have the ability to survive in saturated environments with glyphosate, an herbicide used to eradicate other plants. Glyphosate interferes with the vital metabolism of plants, but not with transgenic plants for which an alternative metabolic pathway was generated through bioengineering. Since 1996, when GM soy was introduced in Argentina, its use has continued to expand due to the high profit generated by its commercialization and easy harvest [12], as the extension of this crop increases, so does the use of glyphosate. Currently, Argentina is using 240,000 tonnes of glyphosate per year. This has increased year-on-year as a consequence of herbi- 
cide-resistant weeds requiring higher doses of glyphosate and the combined use of other herbicides as 2.4D, atrazine, etc. [13]. This increase has resulted in $5 \mathrm{~kg}$ of glyphosate per person per year as potential exposure burden for all inhabitants of the country, greater in agricultural areas.

Monte Maíz shows the effects of this agricultural model, as is a production boom in the region, a high standard of living among its population, and the relocation of local farmers in the village; these farmers left rural areas and moved with their families work equipment and supplies. Deposits of agricultural equipment are multiplying inside the village (twenty-two in total), the largest deposits in town are in R15, and are five pesticide storage sites. A total of 650 tonnes of glyphosate per year is concentrated, manipulated and has surrounded the town, which now faces fields that are sprayed daily. Glyphosate was found in 100\% of soil and husk dust samples. The concentration was 10 times higher than that of other pesticides. This demonstrates that, of all pesticides that pollute the environment, glyphosate is the most prevalent. Concentrations found in inner town are several times higher than in the soil in cultivated fields (see Table 1), reaffirming the impression that the town is at the operational center of the sprayed area. Glyphosate is also high in grain dust, it is also accompanied by other pesticides which rule their presence inside the village due to their use in gardening.

In metalwork factories, no significant pollution was found. The density per $\mathrm{km}^{2}$ of the source of electromagnetic radiation such as cell site, high voltage power lines, and electrical voltage transformers is low compared with source electromagnetic radiation density in big cities, which minimizes the value of this pollution. Nueva Cordoba, a neighborhood of Cordoba city, which is located on the same surface as Monte Maíz with a larger population, has nine cell sites, while there are only two towers in Monte Maíz [14], although, a weakness of the study is the lack of electromagnetic radiation direct measurements.

Moreover, household garbage management, sewage, and contaminant-free water (for 16 years now) remove these contaminating factors from the observed pathologies. Thus, pollution with glyphosate and to a lesser extent with other pesticides is the predominant factor in the environmental contamination analysis of Monte Maíz.

The Monte Maíz 2014 crude cancer incidence rate is $276 \%$ higher than Cordoba city 2009 for RPT in last published data [5]; GLOBOCAN 2012 [6] and Health Ministry [10] estimated for Argentina an incidence 317\% lower than in Monte Maíz (Table 3). RPT estimates 9,000 new cancer cases per year for the entire province; in the observed population, there should be 13.9 new cases in 2014, for IARC's references, the annual figure should not exceed 11 cases, however there are 35 cases in 2014. RPT data is generated from oncologist and pathologist reports and state statistics offices; there may be underreporting of cases. By contrast, our data may be biased due to the fact that they are self-referenced, and while this is a limiting factor for any study of disease through surveys, it is unlikely in some less prevalent pathology where, on the contrary, the most common error is type II. The biases that arise when comparing different 
populations such as a farming town (Monte Maíz) and a large city (Cordoba City) refer to a greater relative weight of elderly people in farming towns that require adjustment rates by age; they do not substantially alter the differences in incidence found. The Monte Maíz adjusted incidence of cancer rate resulted in being 208\% greater than in Cordoba city. As a secondary analysis but in view of the age bias, we also contrasted the age structure of the cancer cases reported by the RPT in years 2004-2009 with Monte Maíz age structure cancer cases data 2010-2014, compared between patients under 44 and over 45 years old age, and found that $22 \%$ of the patients in Monte Maíz are younger than 44 years old and $11 \%$ in the entire province. The OR for cancer in people younger than 44 in Monte Maiz was 1.88 (CI: 1.31 - 2.70) p-value: 0.001. It was observed that cancer appears in younger people in Monte Maíz; the findings are consistent with the observations made by local doctors in two ways: absolute increase of cancer and a greater relative presence of young cancer patients.

Cancer prevalence is $240 \%$ higher than what GLOBOCAN 2012 (IARC 2012) report for Argentina (Table 3). The urban area (radius census) with most important pesticide deposits, R15, showed a higher rate of cancer prevalence compared to all other radius into which the town was divided, suggesting a relation dose (exposure)-effect that would strengthen the inference of the relationship. Smoking did not influence and cancer locations do not differ from those reported by the RPT for the entire Province [5]. Simultaneously (March 2015), an environmental health analysis conducted for National University of Rosario (UNR) in another farming town (Maria Juana), located $300 \mathrm{~km}$ from Monte Maíz, detected 80 cancer patients among 3940 inhabitants (unpublished data) with a prevalence rate of 2013/100,000, very similar to our results. The UNR also analyzed the environmental health status of 19 towns in the agricultural region and found an increase of 2 - 4 times the expected cancer prevalence [15].

The Monte Maíz cancer mortality rate was $299 \%$ higher than the Cordoba city. From RPT, the average cancer mortality rate in the Union District is also twice as high as in Cordoba city [5]. From Health Ministry 20\% of deaths in Argentina were due to cancer [16], it is also $20 \%$ cancer mortality in Cordoba city. However, according to death certificates in Monte Maíz, cancer deaths were 39\% in 2013 and 34\% in 2014. Serrano published in 2013 a study of cancer mortality in San Vicente, an agricultural town $290 \mathrm{~km}$ of Monte Maíz, where cancer multiplied in recent years together with the expansion of soybean cultivation and use of pesticides [17]. A multi-center study sponsored by the Health Ministry in 2012 reports substantial mortality differences between soybean farming villages (that used glyphosate) and cattle-raising villages (that do not use glyphosate), in Avia Terai, Campo Largo, and Napenay village, there were cancer deaths with frequencies of $31.3 \%, 29.8 \%$ and $38.9 \%$, respectively, whereas in Cole-Lai and Charadai, only $5.4 \%$ and $3.1 \%$ [18]. Another study as well, sponsored by the Health Ministry on pesticide exposure and health found a connection between male cancer mortality and breast cancer mortality distribution with glyphosate use rate for districts [19]. During 2015 the UNR School of Medicine studied the 
environmental health of the agricultural town San Salvador in Entre Rios, found that almost $50 \%$ of those who died did so for cancer in recent years and high contamination with pesticides, including glyphosate [20].

Cancer and agrochemicals is a mentioned relationship in epidemiological and experimental reports. Leu and Swanson found a strong link between health deterioration and increased cancer rates with glyphosate exposure in the USA [21]. The Monograph Working Group of the IARC in Evaluation of Carcinogenic Risks to Humans in 2015 reviews 1000 studies on glyphosate and chooses 200 relevant paper to conclude that "There is limited evidence in humans for the carcinogenicity of glyphosate. A positive association has been observed for nonHodgkin lymphoma. Also, there is sufficient evidence in experimental animals for the carcinogenicity of glyphosate. Concluding that Glyphosate is probably carcinogenic to humans (Group 2A). There is strong evidence that glyphosate can operate through two key characteristics of known human carcinogens, and that these can be operative in humans. Specifically: there is strong evidence that exposure to glyphosate or glyphosate-based formulations is genotoxic based on studies in humans in vitro and studies in experimental animals; And there is strong evidence that glyphosate, glyphosate-based formulations, and AMPA can act to induce oxidative stress based on studies in experimental animals, and in in-vitro studies in humans" [4].

Studies of glyphosate genotoxicity emphasize the occurrence of damage to the DNA strands that when not repaired nor the cell removed, can lead to cell mutations that are the start of biological onset of cancer [22] [23] [24] [25]. So far, epidemiological and experimental evidence shows that structural and numerical chromosomal aberrations (CAs) generated by genotoxic agents are involved in carcinogenesis [26]. Near Monte Maíz, in Marcos Juarez City, two studies showed twice the frequency of CAs in environmentally exposed people to glyphosate or other pesticides [27] and genotoxicity in children exposed to pesticides comparing to not expose [28].

Our epidemiological link between environmental glyphosate and cancer seems consistent regarding the incidence, prevalence, and mortality, the strength of the association appear important and highlights the fact that families with farming activities have a greater risk of cancer than families no farming, probably due to greater direct exposure to glyphosate; although recognize that the ecological fallacy cannot be discarded from this analysis. The change in time sequence could not be stated in this cross-sectional study, but local doctors noted changes in the disease profile since the introduction of GM seeds and the massive use of glyphosate. The results of this study are also important because they describe a health problem in the environment where the people are living.

\section{Conclusion}

This research detected an urban environment severely polluted by glyphosate and other pesticides and identified high frequencies of cancer, suggesting a link between environmental exposure to glyphosate and cancer, although this was an 
exploratory and observational design unable to make direct causal assertions. However, it is necessary to recognize the associations based on the analysis of the differences between exposure variables and high cancer prevalence, incidence, and mortality that must be verified with studies specifically designed for this purpose; further research is needed to reveal the exact relationship between cancer and glyphosate.

\section{Acknowledgements}

SUMA 400 Program, Secretary of University Extension from UNC that made it possible to travel with a team of 70 people to Monte Maíz. To the Municipality of Monte Maíz, that facilitated the stay of our team during the 5-day field work. To the professors and students of Medicine and Geography from UNC), to the professors and students of Chemistry from the Faculty of Naturals and Exact Sciences of National University of La Plata, that conducted the chemical field work at Monte Maiz.

\section{Conflict of Interest}

The authors declare they have no actual or potential competing financial interests.

\section{Supported}

The authors did not provide support for the work subsidies, grants or contributions of equipment or drugs.

\section{References}

[1] Lopez, G. (2010) La Agricultura Argentina al 2020, Fundación producir conservando. https://www.ucema.edu.ar/conferencias/download/2010/20.08.pdf

[2] Avila-Vazquez, M. (2014) Agricultura Tóxica y Pueblos Fumigados en Argentina. Universidad y Salud. Revista $+E, 4,28-35$.

http://bibliotecavirtual.unl.edu.ar/publicaciones/index.php/Extension/article/view/4 $\underline{586 / 6977}$

[3] Avila-Vazquez, M. and Nota, C. (2010) Report from the $1^{\text {st }}$ National Meeting of Physicians in the Crop-Sprayed Towns. Faculty of Medical Sciences, National University of Cordoba.

http://www.reduas.com.ar/wp-content/uploads/downloads/2011/10/INGLES-Repor t-from-the-1st-National-Meeting-Of-Physicians-In-The-Crop-Sprayed-Towns.pdf

[4] Guyton, K.Z., Loomis, D., Grosse, Y., El Ghissassi, F., Benbrahim-Tallaa, L., Guha, N., et al. (2015) Carcinogenicity of Tetrachlorvinphos, Parathion, Malathion, Diazinon, and Glyphosate. Lancet Oncology, 16, 490-491. http://monographs.iarc.fr/ENG/Monographs/vol112/mono112-09.pdf

[5] Registro Provincial de Tumores. Informe sobre Cáncer en la Provincia de Córdoba. 2004-2009. Córdoba, Editorial de la Provincia de Córdoba. 2013.

http://reduas.com.ar/wp-content/uploads/downloads/2016/09/Libro-Cancer-Provin cial.pdf

[6] Globocan 2012: Estimates incidence, mortality, and prevalence worldwide in 2012. IARC-WHO. http://globocan.iarc.fr/Pages/Map.aspx 
[7] Scribner, E.A., Battaglin, W.A., Gilliom, R.J. and Meyer, M.T. Concentrations of Glyphosate, Its Degradation Product, Aminomethylphosphonic Acid, and Glufosinate in Ground- and Surface-Water, Rainfall, and Soil Samples Collected in the United States, 2001-06: US Geological Survey. Scientific Investigations Report 2007$5122,111 \mathrm{p}$.

[8] American Public Health Association (APHA) (2012) American Water Works Association (AWWA) \& Water Environment Federation (WEF). Standard Methods for the Examination of Water \& Wastewater, 22nd Edition.

[9] Municipalidad de Monte Maíz (2015) Información General. http://www.montemaiz.gob.ar/index.php?pageid=68

[10] Instituto Nacional del Cáncer (2012) Análisis de la situación del cáncer en Argentina. http://www.msal.gov.ar/inc/acerca-del-cancer/mortalidad/

[11] Ley 9694 (2009) Provincia de Córdoba. Sistema de Evaluación, Registro y Fiscalización de las Investigaciones en Salud. https://www.unrc.edu.ar/unrc/coedi/docs/salud/sal coeis ley9694.pdf

[12] Aizen, M.A., Garibaldi, L.A. and Dondo, M. (2009) Expansión de la soja y diversidad de la agricultura argentina. Ecologia Austral, 19, 45-54.

[13] REDUAS (2013) The Use of Toxic Agrochemicals in Argentina Is Continuously Increasing. Analysis of Data from the Pesticide Market in Argentina.

http://www.reduas.com.ar/the-use-of-toxic-agrochemicals-in-argentina-is-continuo usly-increasing/

[14] Open Signal (2014) Towers Identifier and Cell Coverage Map. https://opensignal.com/

[15] Fernandez, M. (2015) Hallan mayor incidencia de tumores en el sur santafesino. La Voz del Interior. Sect Ciudadanos.

http://www.lavoz.com.ar/ciudadanos/hallan-mayor-incidencia-de-tumores-en-el-su $\underline{\text { r-santafesino }}$

[16] Abriata, G. and Loria, D. (2006) Análisis de la Mortalidad por Cáncer 1980-2006. Boletín epidemiológico periódico-Enfermedades No Transmisibles.

http://www.msal.gov.ar/inc/images/stories/downloads/publicaciones/equipo medic o/Epidemiologia/Anlisis de la mortalidad por cncer en Argentina 1980-2006.p df

[17] Serrano, A.B. (2013) Incremento de la Mortalidad por Cáncer en una Población Rural. Santo Domingo, provincia de Santa Fe, desde 1991 al 2010. Actas Médicas Santafesinas, Año III, No. 3 24-33.

http://www.colmedicosantafe1.org.ar/images/PDFs/Publicaciones/Actas-Medicas-S antafesinas-N3-2013-08.pdf

[18] Ramirez, M.L., Berlingheri, B., Nicoli, M.B., Seveso, M.C., Ramirez, L., et al. (2012) Relación entre el uso de agroquímicos y el estado sanitario de la población en localidades de los Departamentos Bermejo, Independencia y Tapenagá de la Provincia del Chaco. Departamento de Geografía de la Facultad de Humanidades de la Universidad Nacional del Nordeste, Salud Investiga, Ministerio de Salud de la Nación.

http://redaf.org.ar/wp-content/uploads/2014/05/agroquimicos salud informechaco minsalud.pdf

[19] Diaz, M.P., Antolini, L., Eando, M., Gieco, M., Filippi, I. and Ortiz, P. (2015) Exposición a plaguicidas y salud en Argentina. Salud Investiga, Ministerio de Salud. http://www.lavaca.org/wp-content/uploads/2015/10/agrotoxicos-vs-salud-cap1.pdf

[20] Verzeñassi, D. (2016) Informe Final estudio de investigación perfil de morbilidad de San Salvador, Entre Ríos. Facultad de Ciencias Médicas de la Universidad Nacional 
de Rosario y Municipalidad de San Salvador. http://sansalvadorer.gov.ar/ https://drive.google.com/file/d/0BxleZzzva6 XWWI2UkJSekV1X1U/view

[21] Swanson, N.L., Leu, A., Abrahamson, J. and Wallet, B. (2014) Genetically Engineered Crops, Glyphosate and the Deterioration of Health in the United States of America. Journal of Organic Systems, 9, 6-37.

http://www.organic-systems.org/journal/92/JOS Volume-9 Number-2 Nov 2014Swanson-et-al.pdf

[22] Dallegrave, E., Mantese, F.D., Coelho, R.S., Pereira, J.D., Dalsenter, P.R. and Langeloh, A. (2003) The Teratogenic Potential of the Herbicide Glyphosate-Roundup in Wistar Rats. Toxicology Letters, 142, 45-52.

https://doi.org/10.1016/S0378-4274(02)00483-6

[23] Cava, T. and Könen, S. (2007) Detection of Cytogenetic and DNA Damage in Peripheral Erythrocytes of Goldfish (Carassius auratus) Exposed to a Glyphosate Formulation Using the Micronucleus Test and the Comet Assay. Mutagenesis, 22, 263-268. https://doi.org/10.1093/mutage/gem012

[24] Mañas, F., Peralta, L., Raviolo, J., García Ovando, H., Weyers, A., Ugnia, L., et al. (2009) Genotoxicity and Oxidative Stress of Glyphosate: In Vivo and in Vitro Testing. Environmental Toxicology and Pharmacology, 28, 37-41.

[25] Alvarez-Moya, C., Silva, M.R., Ramírez, C.V., Gallardo, D.G., Sánchez, R.L., Aguirre, A.C., et al. (2014) Comparison of the in Vivo and in Vitro Genotoxicity of Glyphosate Isopropylamine Salt in Three Different Organisms. Genetics and Molecular Biology, 37, 105-110. https://doi.org/10.1590/S1415-47572014000100016

[26] Albertini, R.J., Anderson, D. and Douglas, G.R. (2000) IPCS Guidelines for the Monitoring of Genotoxic Effects of Carcinogens in Humans. International Programme on Chemical Safety. Mutation Research, 463, 111-172. https://doi.org/10.1016/S1383-5742(00)00049-1

[27] Peralta, L., Mañas, F., Gentile, N., Bosch, B., Méndez, A. and Aiassa, D. (2011) Evaluación del daño genético en pobladores de Marcos Juárez expuestos a plaguicidas: estudio de un caso en Córdoba, Argentina. DiáRevista Diálogos, 2, 7-26.

[28] Bernardi, N., Mañas, F., Méndez, A., Gorla, N. and Aiassa, D. (2015) Assessment of the Level of Damage to the Genetic Material of Children Exposed to Pesticides in the Province of Córdoba. Archivos Argentinos de Pediatria, 113, 126-132. http://www.sap.org.ar/docs/publicaciones/archivosarg/2015/v113n2a06e.pdf

\section{Submit or recommend next manuscript to SCIRP and we will provide best service for you:}

Accepting pre-submission inquiries through Email, Facebook, LinkedIn, Twitter, etc. A wide selection of journals (inclusive of 9 subjects, more than 200 journals)

Providing 24-hour high-quality service

User-friendly online submission system

Fair and swift peer-review system

Efficient typesetting and proofreading procedure

Display of the result of downloads and visits, as well as the number of cited articles

Maximum dissemination of your research work

Submit your manuscript at: http://papersubmission.scirp.org/

Or contact ijcm@scirp.org 